\title{
PRAVILA PETRA PAVLA GLAVARJA ZA ČEBELARSKO VRTNARSKO ŠOLO NA LANŠPREŽU IZ LETA 1781
}

\author{
Andrej ŠALEHAR ${ }^{1}$
}

Delo je prispelo 25. aprila 2013, sprejeto 20. junija 2013. Received April 25, 2013; accepted June 20, 2013.

\begin{abstract}
Pravila Petra Pavla Glavarja za čebelarsko vrtnarsko šolo na Lanšprežu iz leta 1781

Peter Pavel Glavar je objavil pravila za čebelarsko vrtnarsko šolo na Lanšprežu kot prilogo k razpravi »Predlog za dvig čebelarstva na Kranjskem«, ki jo je 17. decembra 1781 predložil kranjski kmetijski družbi. Pravila vključujejo: Osnutek ureditve državnega učitelja čebelarstva, osnutek za vajence, načrt za splošnokoristno čebelarsko vrtnarsko šolo pod gospostvom Lanšprež in pouk za skrbnika. Pravil za čebelarsko šolo po vsebini in v obliki, kot jih je napisal Glavar, po dosedaj znanih podatkih nismo zasledili. Glavar je med drugim predpisal, da bo pouk v deželnem (slovenskem) jeziku, da se bo čebelarilo v skupnih čebelnjakih in da se na osnovi pregledov panjev določi potrebne ukrepe čebelarjenja. Pravila uradno niso bila potrjena in odobrena, kar je preprečil dvorni dekret o ukinitvi javnih učiteljev čebelarstva, ki je bil izdan 31. oktobra 1781. Glavar pa je leta 1781 odprl čebelarsko šolo na Lanšprežu.

Ključne besede: čebelarstvo / zgodovina / izobraževanje / Slovenija
\end{abstract}

\section{UVOD}

V drugi polovici 18. stoletja je bil na Kranjskem na čebelarskem področju je bil nedvomno vodilni Peter Pavel Glavar (1721-1784), duhovnik in lanšpreški gospod (lastnik graščine Lanšprež pri Mirni na Dolenjskem). Imel je veliko praktičnih izkušenj s čebelarjenjem in tudi bogato teoretično znanje. Poudarjal je pomen poučevanja in usposabljanja za čebelarstvo v čebelarskih šolah in pravno ureditev čebelarskih vprašanj. O čebelarski šoli, ki naj bi doprinesla k premagovanju ovir pri izboljševanju čebelarstva, je Peter Pavel Glavar pisal že leta 1768 v
Peter Pavel Glavar's rules for the school of horticulture and bee keeping in Lanšprež in the year 1781

Peter Pavel Glavar has published his rules for the school of horticulture in Lanšprež as an annex to his paper on advancement of bee keeping in Carniola »Predlog za dvig čebelarstva na Kranjskem «) which was on December 17, 1781 submitted to the Carniolan Agricultural Society. The rules include: plan for regulation of the status of the state teacher of apiculture, regulation for the apprentices, plan for the general api- and horticulture school under auspices of estate Lanšprež and learning plan for the curator. The rules for the school of apiculture, as formulated by Glavar, were not found before. Glavar has among other regulations also defined that teaching should be carried out in local (Slovene) language, bee keeping should be performed in joint apiaries and bee keeping measures should be taken after inspection of bee hives. The rules were not accepted nor approved formally, due to the court decret on abolition of public teachers for apiculture, published on October 31, 1781. Glavar opened the school of apiculture in Lanšprež in 1781.

Key words: apiculture / history / education / Slovenia

svojem Odgovoru - Glavar (1768 - cit. Mihelič, 1934). Prva čebelarska šola je odprla vrata leta 1770 v Augartenu na Dunaju in prvi učitelj čebelarstva je bil Slovenec Anton Janša. Dunajska dvorna pisarna je po izdaji čebelarskega zakona $\mathrm{z}$ instrukcijo za čebelarske mojstre (Bienenzuchtverbreitung...., Instruktion....., 1775) tega poslala skupaj s šestimi izvodi Vollständige Lehre von der Bienenzucht (prevod: Popolen nauk o čebelarstvu - Janša, 1775) tudi na Kranjsko, kjer ga je prejela tudi kranjska kmetijska družba. Zaprosila je nekatere člane, med njimi tudi Petra Pavla Glavarja, da napišejo mnenje, če bi bilo koristno uveljaviti ta čebelarski patent tudi na Kranj-

1 Univ. v Ljubljani, Biotehniška fak., Odd. za zootehniko, SI-1230 Domžale, Slovenija 
skem. Glavar je zaradi bolezni in drugih zadržkov odgovoril obsežno a pozno, ko ji je poslal: »Poročilo kmetijski družbi v Ljubljani z dne 17. decembra 1781 o potrebnih ukrepih za povzdigo čebelarstva na Kranjskem, o ustanovitvi čebelarske šole in organizaciji vaških čebelarskih zadrug. " Poročilo obsega 43 listov, na koncu pa so dodana pravila za čebelarsko šolo.

Namen razprave je predstavitev Glavarjevih pravil za čebelarsko vrtnarsko šolo na Lanšprežu, njihova strokovna presoja in pomen za razvoj slovenskega in svetovnega čebelarstva.

\section{MATERIAL IN METODE DELA}

Prva napotila za iskanje gradiv so bila najdena $\mathrm{v}$ splošnih objavah o Petru Pavlu Glavarju in še posebej v sestavkih, ki jih je napisal Mihelič (1934 in 1976). Veliko koristnih informacij je tudi v objavah Dolenc (1983/1987) in Glonar (1938). Osnovna gradiva so bila najdena v Arhivu Republike Slovenije (ARS), kjer so bili pregledani naslednji fondi:

- SI ARS 869 Glavar Peter Pavel, 1751-1784 (Fond)

- SI ARS 751 Gospostvo Lanšprež, 1708-1864 (Fond)

- SI ARS 1073 Zbirka rokopisov, 1/24 r, 13. st.1941 (Fond)

Najdene rokopisne listine smo posneli in poiskali pomoč za čitanje in prevod, kar je opravil g. France Baraga. Za prevode je bila opravljena strokovna redakcija, ki sta jo opravila g. Janez Gregori, prof. biol. in avtor tega sestavka.

\section{REZULTATI}

\subsection{SPLOŠNI ZAPISI O PRAVILIH}

Glavarjeva pravila za čebelarsko vrtnarsko šolo na Lanšprežu so sestavni del dokumenta, ki ga je predstavil Dolenc (1983/1987): »Glavar, Peter Pavel: (Predlog za dvig čebelarstva) Iz leta 1782, 55 listov, 35,0 × 23,0 cm; papir, debele sive platnice iz lepenke, nemščina, gotica, kurziva, lepa izpisana pisava. To je predlog P. P. Glavarja na Hochlöbliche Kais. Königliche Ackerbauss und Künste Geselschaft za dvig čebelarstva.«

Mihelič (1976) o dokumentu piše: "Poročilo kmetijski družbi v Ljubljani z dne 17. decembra 1781 o potrebnih ukrepih za povzdigo čebelarstva na Kranjskem, o ustanovitvi čebelarske šole in organizaciji vaških čebelarskih zadrug. To je Glavarjev doslej znani zadnji čebelarski spis, obsega 43 listov. Za poročilom sledi še: Osnutek za delo čebelarskih učiteljev, osnutek o pouku učencev, načrt splošne čebelarsko-vrtnarske šole na gospostvu Lanšprež in načrt pouka za skrbnike. "Mihelič (1989) pa sporoča: »Vnovič je leta 1781 poslal Kmetijski družbi v Ljubljani obširen dopis, $v$ katerem se zavzema za ustanovitev čebelarske šole na Lanšprežu, za ustanavljanje vaških čebelarskih združenj, navaja program pouka na čebelarski šoli idr. Za učitelja se ponuja Glavar sam. Poučeval bi brezplačno, zaslužek, ki bi ga prejemal, pa bi porabil za nakup čebel za podložnike. Ker na vse to ni dobil od oblasti nobenega odgovora, je sam organiziral čebelarski pouk za podložnike in prvo čebelarsko zadrugo.«

O Glavarjevih pravilih poroča tudi Oražem (1999), in sicer o rokopisu, kjer je predlagana čebelarska šola, da naj bi bila "na Lanšprežu, ker je tam za praktičen pouk že na voljo 130 panjev. Glavar bi bil učitelj, ki pa bi poučeval brezplačno in bi denar za plačilo, ki bi ga prejemal, uporabil za nakup panjev za podložnike. Glavar še predlaga kakšen naj bi bil predmetnik čebelarsko-vrtnarske šole, ki naj bi dopolnilno poučevala učence tudi branja in pisanja. Pouk bi bil za učence brezplačen....za vrtnarje bi sprejemali $v$ službo le tiste, ki so vešči tudi čebelarstva. Šola bi se vsako leto začela $v$ začetku marca in bi trajala do konca oktobra. Ob koncu dvoletnega šolanja naj bi vsak učenec dobil na stroške stanovske blagajne po en panj čebel za začetek čebelarjenja«.

\subsection{PREDSTAVITEV PRAVIL}

\subsubsection{A. PRAVILO: OSNUTEK UREDITVE DRŽAVNEGA UČITELJA ČEBELARSTVA}

Pravilo »Osnutek ureditve državnega učitelja čebelarstva« vključuje 17 odstavkov.

Delo državnega učitelja čebelarstva na čebelarsko vrtnarski šoli na Lanšprežu je bil pripravljen prevzeti Glavar sam in to brezplačno za dobo šestih let. Tako kot se je že v Odgovoru (1768) ponudil, da bo ob nedeljah brezplačno poučeval o čebelarjenju. S sredstvi, $300 \mathrm{gld}$, kolikor je bila takrat letna plača državnih učiteljev čebelarstva, je nameraval ustanoviti sklad za nabavo čebeljih panjev, da bi ustanovili čimveč skupnih čebeljnjakov. Glavarjev načrt je bil povsem realen, a žal prepozen, ker ga je prehitel dvorni dekret $\mathrm{z}$ dne 31.10.1781, ko so bili zaradi prevelikih stroškov ukinjeni vsi učitelji čebelarstva in za katerega Glavar po vsej verjetnosti še ni vedel.

Podobno kot na drugih takratnih čebelarskih šolah je tudi Glavar predvidel, da bo pouk brezplačen. Tako je določal čebelarski patent Marije Terezije iz leta 1775 (Bienenzuchtverbreitung.... 1775). Določilo, da bo pouk v deželnem (slovenskem) jeziku je potrebno posebej poudariti in je posebnega pomena. To je izjemno določilo za Kranjsko konec 18. stoletja in velik prispevek $\mathrm{k}$ 


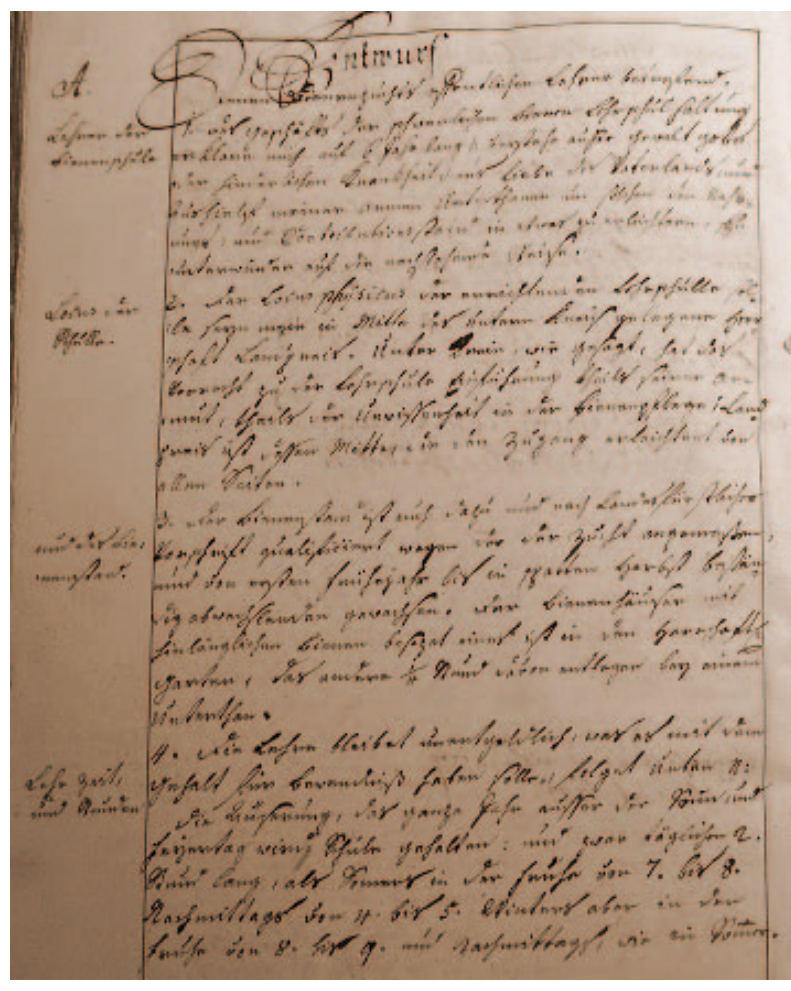

Slika 1: A. Pravilo: Osnutek ureditve državnega učitelja čebelarstva - uvodna stran - Glavar 1781 (Zbirka rokopisov AS SI 1073, 1/24 r, 13. st.-1941)

Figure 1: A. Rule: Plan for regulation of the status of the state teacher of apiculture - title page - Glavar 1781 (Zbirka rokopisov-AS SI 1073, 1/24 r, 13. st.-1941)

uveljavitvi slovenskega jezika. Glavar je šolanje namenil podložnikom, ki so bili vešči le domačega slovenskega jezika. V dvorni odredbi: Inštrukcija za čebelarske mojstre (Instruktion für....., 1775) je med drugim določeno, da morajo biti predavanja razumljiva. Marija Terezija je v omenjeni instrukciji tudi odredila, da je osnova za pouk na javnih čebelarskih šolah Janšev čebelarski nauk. Glavar to pritrjuje, a hkrati tudi določa, da naj se doda še vse stvari, ki jih Janša ne obravnava. To je razvidno iz razlik med Janševo Razprava o čebelnih rojih in Glavarjevim delom Pogovor o čebelnih rojih, ki jih je predstavil Mihelič (1976). Ugotovil je, da je v Glavarjevi knjigi med 691 odstavki kar 296 (42,8 \%) odstavkov originalnih Glavarjevih, le 233 odstavkov (33,7 \%) originalnih Janševih in 162 odstavkov $(23,4 \%)$ od Glavarja dopolnjenih Janševih odstavkov. Glavarjeva slovenska knjiga o čebelarstvu, ki jo je napisal leta 1776, ni bila natisnjena, ker naj bi bila izgubljena. Glavar poudarja potrebo po slovenskem čebelarskem čtivu in da jo je treba napisati na novo, če se že napisane ne bo našlo.

Glavar je poznal določilo, da morajo učitelji čebelarstva opraviti šolanje na dunajski čebelarski šoli in uspe- šno tudi izpit za učitelja čebelarstva (5. člen - Instruktion...., 1775). Temu se je hotel nekako izogniti, ko piše, da sicer nima nič proti preverjanju na Dunaju, a meni, da to ni potrebno zaradi visokih potnih stroškov, starosti in njegovega splošno znanega znanja o čebelarjenju in sposobnosti za javno poučevanje. Glavar v svojih pravilih dosledno uveljavlja določila čebelarskega patenta iz leta 1775, še posebej, da je čebelarstvo oproščeno vseh dajatev kot na primer cestnina pri prevozu panjev na in iz paše, mitnine in drugo.

Zanimiva je tudi ideja skupnih čebelnjakov, ki bi imeli prednost pred zasebnimi čebelnjaki. Glavar to predlaga iz različnih razlogov in med njimi je tudi ta, da bi te skupne čebelnjake vodili in oskrbovali usposobljeni skrbniki, ki bi se izšolali na čebelarsko vrtnarski šoli. $\mathrm{Za}$ zasebne čebelnjake, kjer je po čebelarskem patentu vsakemu podložniku dovoljeno poljubno število panjev, meni, da bodo ti zaradi skupnih čebelnjakov postopoma v obdobju dveh let ukinjeni sami po sebi.

\subsubsection{B. PRAVILO: OSNUTEK ZA VAJENCE}

Pravilo »Osnutek za vajence« vključuje 10 odstavkov.

Za vajence Glavar predpisuje, da so stari od 15 do 20 let, uka željni, pošteni in sposobni fantje. Prednost daje tistim, ki znajo brati in pisati $\mathrm{v}$ deželnem (slovenskem) jeziku. Če pa tega ne znajo, jih bodo to učili graščinski gospodarski uslužbenci, da bodo, ko bodo nastavljeni za skrbnike čebelnjakov, lahko vodili potrebno evidenco. Glavar priporoča, da bi morali bodoči vrtnarji oskrbovati tudi čebelnjake, kar naj bi bilo tudi zakonsko predpisano. Šolanje se prične na začetku marca in konča konec meseca oktobra. Vajenci, ki bodo usposobljeni, bodo odpuščeni in vsaj najboljši bodo za nagrado dobili en panj. Drugi, ki ne bodo izdelali, pa ostanejo na šoli toliko časa, da se usposobijo. V zimskem času bi se ti usposabljali tudi $\mathrm{v}$ mizarstvu, da bodo vešči v izdelavi panjev in podloge zanje.

\subsubsection{PRAVILO: NAČRT ZA SPLOŠNOKO- RISTNO ČEBELARSKO VRTNARSKO ŠOLO POD GOSPOSTVOM LANŠPREŽ}

Pravilo »Načrt za splošnokoristno čebelarsko vrtnarsko šolo pod gospostvom Lanšprež« vključuje 17 odstavkov.

Pri čebelarsko vrtnarski šoli pod gospostvom Lanšprež je dan poudarek skupnim čebelnjakom, ki bi imeli po 120 panjev. Glavnico, ki naj bi bila stalna za njihovo ureditev, bi predstavljalo plačilo za državnega učitelja v 


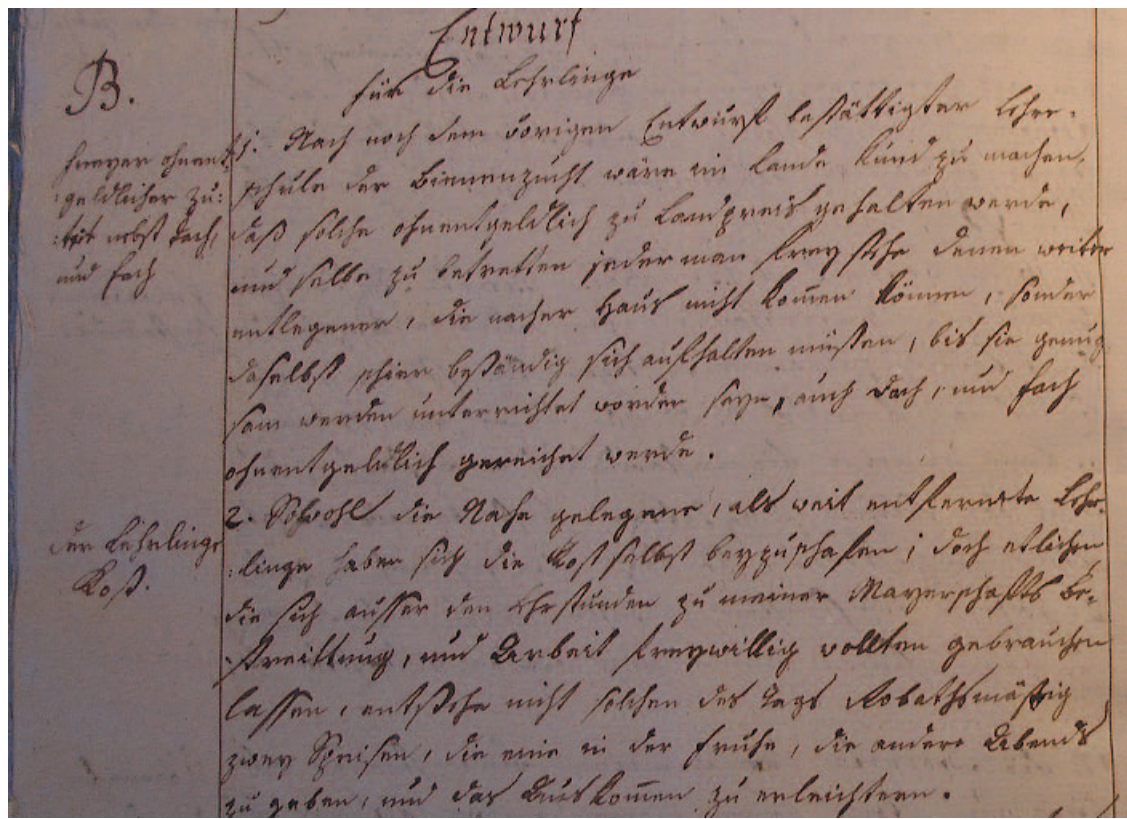

Slika 2: B. Pravilo: Osnutek za vajence - uvodna stran - Glavar 1781 (Zbirka rokopisov - AS SI 1073, 1/24 r, 13. st.-1941)

Figure 2: B. Rule: Regulation for the apprentices - title page - Glavar 1781 (Zbirka rokopisov - AS SI 1073, 1/24 r, 13. st.-1941)

višini 300 gld in v šestih letih bi se zbralo skupaj 1800 gld, kar bi omogočilo postavitev in ureditev šestih skupnih čebelnjakov. Tudi za kritje med letom nastalih dodatnih stroškov je Glavar pripravljen prispevati. Vsak skupni čebelnjak ima dobro poučenega skrbnika, ki je zavezan od marca do oktobra od jutra do večera paziti na čebele in mu pripada primerna letna plača iz skupnega dobička.

Nove čebelje družine (naravni in umetni roji) so namenjene za dopolnitev ali nove skupne čebelnjake in se ne štejejo $\mathrm{v}$ prirejo. V skupno čebelarstvo lahko vstopi pa tudi izstopi vsak lanšpreški podložnik. Nadzor in vodstvo skupnih čebelnjakov ima gospostvo Lanšprež, vsak pa ima tudi odbor. Skrbnik beleži vse stroške (čebelarska oprema, deske za panje in drugo) in prihodke od medu ter voska. Ob koncu leta se naredi letni obračun. Od čistega letnega dobička se najprej nameni $10 \%$ za napravo in postavitev novih čebelnjakov ter za nakup novih panjev, nato se izplača skrbnikova plača in ostanek nameni članom skupnosti (3/4 podložnikom in $1 / 4$ gospostvu). Glavar meni, da bi imeli pri izplačilu prednost revnejši podložniki.

\subsubsection{PRAVILO: POUK ZA SKRBNIKA}

Pravilo »Pouk za skrbnika« vključuje 32 odstavkov. Glavar odločno trdi, da je za vzrejo čebel potrebno znanje ter usposobljenost in meni, da so za skrbnike primerni le iznajdljivi, marljivi, trezni, zvesti in dobro vzgojeni ljudje. Skrbnik mora svojemu gospodu redno poročati in točno izvesti vse njegove ukaze. Prepovedano je svojeglavo in samovoljno postopanje, ukrepanje.

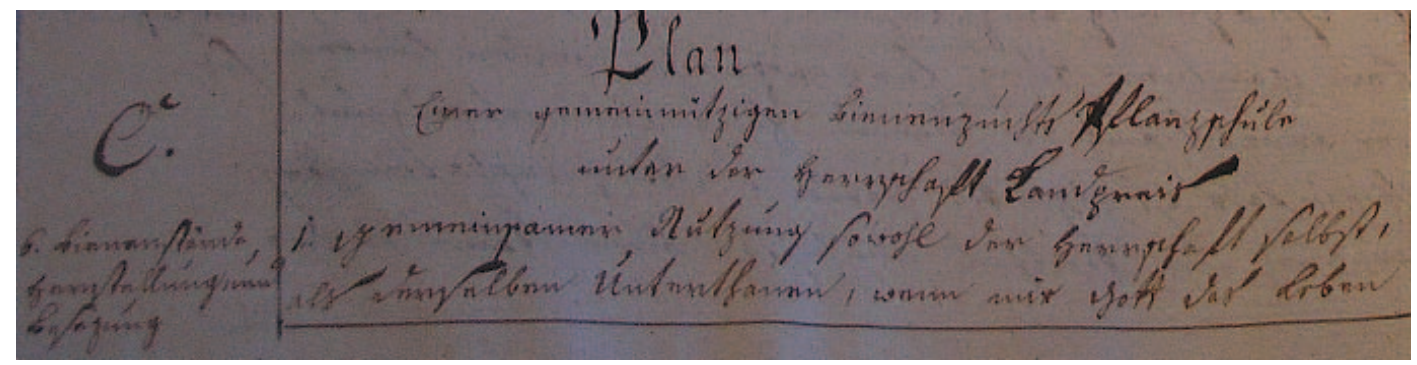

Slika 3: C. Pravilo: Načrt za splošnokoristno čebelarsko vrtnarsko šolo pod gospostvom Lanšprež - uvodna stran - Glavar 1781 (Zbirka rokopisov - AS SI 1073, 1/24 r, 13. st.-1941)

Figure 3: C. Rule: Plan for the general Api-and Horticulture school under auspices of estate Lanšprež - title page - Glavar 1781 (Zbirka rokopisov - AS SI 1073, 1/24 r, 13. st.-1941) 


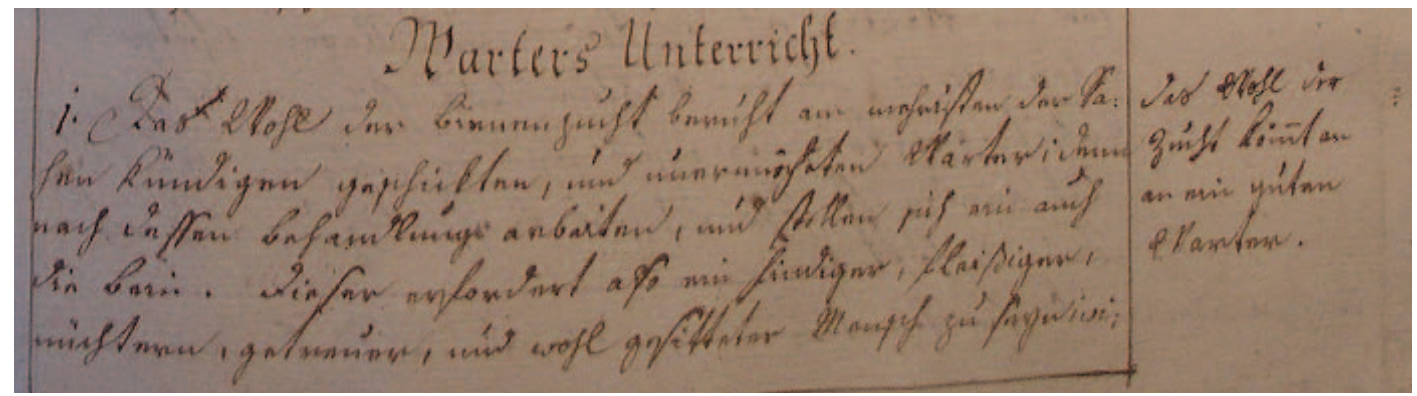

Slika 4: D. Pravilo: Pouk za skrbnika - uvodna stran - Glavar 1781 (Zbirka rokopisov - AS SI 1073, 1/24 r, 13. st.-1941)

Figure 4: D. Rule: Learning plan for the curator - title page - Glavar 1781 (Zbirka rokopisov - AS SI 1073, 1/24 r, 13. st.-1941)

Zahtevano je, da je skrbnik stalno, vseh osem mesecev, prisoten pri čebelnjaku in ni mu dovoljeno, da bi si iskal dodatne zaslužke. Dovoljeno je, da se ob prostem času ukvarja s pletenjem, izdelavo slamnikov in podobnim, za kar naj bi bil posebej izučen ter si tako lahko pridobi stranski zaslužek. Za zagotovitev stalne prisotnosti je namenjena tudi v bližini čebelnjaka postavljena uta, da bi ga varovala pred soncem in dežjem.

Podrobneje o Glavarjevem načinu čebelarjenja, ki ga je zasnoval na osnovi svojih dolgoletnih izkušenj, je pisal Mihelič (1976). Tako je v pravilu tudi zasnoval učenje tehnike čebelarjenja: preglede, ocenjevanja, razvrščanja in označevanja panjev, spremljanja pregledov panjev, dogodkov in ukrepanj ter o vsem tem vodenje evidence, zapisnikov. Preglede panjev opravi trikrat na leto - spomladi, ob kresu in na vse svete - in pri tem opravi čiščenje panjev ter oceni moč družine (pet razredov), zalego (pet razredov) ter hudo gnilobo čebelje zalege. $\mathrm{Na}$ osnovi teh ocen razvrsti panje v pet razredov in za vsak razred določi postopke potrebnih čebelarskih opravil: krmljenje, ponovni pregledi, dodajanje matic, podstavkov in nadstavkov in drugo. Zelo sistematičen, strokoven in pedagoško uspešen je pristop, ki ga Glavar omenja v zasnovi že v Odgovoru (Glavar, 1768). V Janševih knjigah ta sistem ni opisan. Nekatera opisana čebelarska opravila so $v$ rabi še danes.

Ob cvetenju ajde je najpomembnejši čas nabiranja medu in skrbnik pazi, da imajo čebele za delo dovolj prostora $\mathrm{z}$ dodajanjem podstavkov in nadstavkov. Jeseni se opravi tehtanja, pripravi panje za zimo in poskrbi za zalogo medu za pitanje. Vsakodnevna opravila vključujejo jutranji in popoldanski pregled ter večkrat dnevni obhod čebelnjaka, preglede posameznih sumljivih panjev in opazovanje stanja čebel. Pozimi skrbnik pazi, da v panje ne zaidejo škodljivci, kot so miši, rovke.

Skrbnik naj bi ne imel svojih čebel, da ne bi prišlo do suma poneverb pri krmljenju, rojih in podobno. Ima pa pravico, da da svoje čebele pri jesenskem tehtanju v skupno rabo, kar se mu celo svetuje, da bo skrbneje varoval celoten čebelnjak.

\section{RAZPRAVA IN ZAKLJUČKI}

Čebelarski nauk, morda bolje učni načrt čebelarstva, po katerem je na Dunaju učil Janša, je kmalu po njegovi smrti zapisal Kratzer (1774). Predstavil ga je kot deset pogovorov, ki se zvrstijo $\mathrm{v}$ petih dneh. $\mathrm{Na}$ koncu so dodana kratka navodila, kako in na kaj je treba zlasti paziti pri čebelarjenju vsak mesec. Janšev način čebelarjenja je poimenoval nov avstrijski način gojenja čebel. Predpisan je tudi v čebelarskem patentu in priloženih instrukcijah za čebelarske mojstre - (Bienenzuchtverbreitung...., Instruktion......, 1775). To so med prvimi zapisi o poučevanju čebelarstva. V drugi točki Instruktion (1775) je zapisana zahteva, da se pri naročilu čebelnjakov s potrebnimi panji upoštevajo preskušena načela prvega dunajskega čebelarskega učitelja Janše. Peta točka določa, da ne more biti v deželah nihče sprejet za javnega učitelja čebelarstva, kdor se ni učil na glavni čebelarski šoli na Dunaju, kdor ni bil izprašan od tamkajšnega prvega učitelja in kdor ne prinese s seboj spričevala, da ni samo usposobljen, da sam vodi čebelarstvo, ampak da ima tudi sposobnosti, da o tem poučuje tudi druge.

Pravila za čebelarsko šolo po vsebini in v obliki, kot jih je napisal Glavar, po dosedaj znanih podatkih nismo zasledili. Napisal je štiri pravila, ki jih je vsebinsko prilagodil udeležencem šole in tudi gospodarskim razmeram na gospostvu Lanšprež. S poučevanjem čebelarstva je želel svojim podložnikom pomagati iz njihovega slabega gmotnega stanja in razširjati čebelarstvo kot pomembno gospodarsko panogo. Pri tem je poleg tedanjih splošno znanih tehnik čebelarjenja upošteval tudi zakonska določila Marije Terezije in svoje dolgoletne izkušnje ter postopke ravnanja s čebelami. Med določili posebej izstopajo:

- pouk v deželnem (slovenskem) jeziku,

- organiziranje skupnih čebelnjakih,

- dopolnjen Janšev čebelarski nauk,

- prednost imajo vajenci, ki znajo brati in pisati,

- šolanje poteka od začetka marca do konca oktobra na posestvu Lanšprež, 
- v skupno čebelarstvo lahko vstopi vsak lanšpreški podložnik,

- stalna prisotnost skrbnika skupnega čebelnjaka od marca do oktobra,

- sistematično pregledovanjev panjev in spremljanje stanja,

- pregledi panjev, razvrstitev $\mathrm{v}$ pet razredov in določitev ukrepov čebelarjenja,

- vodenje zapisnikov o stanju panjev,

- jesenska tehtanja in letni obračun.

Glavar je v pravila vključil svoje bogato teoretično znanje in dolgoletne praktične izkušnje s čebelarjenjem. Glavarjeva pravila niso bili uradno potrjena in odobrena, kar je preprečil dvorni dekret o ukinitvi javnih učiteljev čebelarstva, ki je bil izdan 31. oktobra 1781. Predstavljajo pa enkraten in zelo pomemben dokument iz zgodovine svetovnega in še posebej slovenskega čebelarstva. Iz Glavarjevega pisma Tomlju $\mathrm{z}$ dne 28. novembra 1781 (cit. Glonar - 1938) pa je razvidno, da je Glavar čebelarsko šolo odprl, ker piše "Moji dečki......sedaj imam vsak večer z njimi pouk, ki ga zvesto poslušajo.."

\section{ZAHVALA}

Gospod France Baraga je prečital in prevedel Glavarjeve rokopise. Gospod Janez Gregori, prof. biol., je nesebično pomagal pri strokovni redakciji Glavarjevih pravil. Obema se najtopleje zahvaljujem.

\section{VIRI}

Bienenzuchtsverbreitung, 8. april 1775. 1786-1787. V: Sammlung Verordnungen und Gesetze vom Jahre 1740. bis 1780. Dunaj, 7, 1680: 204-208

Dolenc M. 1983/1987. Bibliografija rokopisnih ljudsko-medi- cinskih bukev in zapisov s slovenskega etničnega območja. Slovenski etnograf, 31: 31-74

Glavar P.P. 1768. Vorschlag Beantwortung zur Verbesserung der Bienenzucht in den Kaysl. Königl. Erb-ländern (Prevod: Predlog odgovora za izboljšanje čebelarstva v c. kr. dednih deželah). Iz leta 1768, 26 str. (AS SI 869 Glavar Peter Pavel, 1751-1784)

Glavar P.P. 1934. Odgovor na predlog za izboljšanje čebelarstva v c. kr. dednih deželah. Napisano 1768, prevod Mihelič Stane. V: Anton Janša. Slovenski čebelar. Mihelič S. (ur.). Ljubljana, Čebelarsko društvo za Slovenijo: 11-38

Glavar P.P. Hochlöbliche Kais. Königliche Ackerbauss und Künste Geselschaft (Predlog za dvig čebelarstva). V dodatku so pravila za čebelarsko vrtnarsko šolo na Lanšprežu. Iz leta 1781, 55 listov. (Zbirka rokopisov - ARS SI 1073, 1/24 r, 13. st.-1941)

Glonar J. 1938. Peter Pavel Glavar. Slovenski čebelar, 41, 7: 105-109, 8: 121-123, 9: 139-140, 10: 152-154, 11: 169-171, 12: $185-186$

Instruktion für die Bienenmeister. 1786-1787. V: Sammlung Verordnungen und Gesetze vom Jahre 1740. bis 1780 . Dunaj, $7: 208-210$

Janša A. 1775. Vollständige Lehre von der Bienenzucht. Wien. http://www.dedi.si/dediscina/401-popoln-nauk-o-cebelarstvu (8. avg. 2012)

Kratzer J.A. 1774. Physikalisch-praktische Diskurse über die sämmtliche Bienenzucht zum Nutzen und Unterricht fur alle okonomischen Liebhaber der neu eingerichteten osterreichischen Bienenpflege. Wien: 154 str. http://gdz.sub.uni-goettingen.de/dms/load/img/?PPN=PP N636577872\&IDDOC $=613467$ (7. apr. 2013)

Mihelič S. 1934. Anton Janša. Slovenski čebelar. Njegovo življenje, delo in doba. Ljubljana: 163 str.

Mihelič S. 1976. Peter Pavel Glavar, čebelar, čebelarski pisec, učitelj in organizator. V: Ob 200-letnici pisane besede o slovenskem čebelarstvu. Mencej M. (ur.). Ljubljana: 20-65

Oražem F. 1999. Peter P. Glavar - čebelar. V: Glavarjev simpozij v Rimu. Škulj E. (ur.). Celje: 177-186

Postave in zaukazi o čebelarstvu. 1873. Slovenska čebela: 1, 9: 68-70, 12: 95-96

Postave in zaukazi o čebelarstvu. 1874. Slovenska čebela: 2, 1 : 3-4 


\section{PRILOGA - PRAVILA}

\begin{tabular}{ll}
\hline A. pravilo & Osnutek ureditve državnega učitelja čebelarstva \\
\hline Učitelj čebelarske šole & 1. Izjavljam, da sem iz ljubezni do domovine in v pomoč mojim revnim podložnikom, ki bi \\
& jim želel nekoliko olajšati oskrbljenost s hrano in davčni položaj, za šest let pripravljen prevzeti \\
posel težavnega poučevanja čebelarstva (seveda, če tega ne prepreči kaka bolezen, kar je v božji \\
domeni), in to na sledeči način.
\end{tabular}

Kraj šole

2. Kraj, kjer naj bi se ustanovila šola, bodi moje gospostvo Lanšprež, ki se nahaja sredi Dolenjske. Kakor rečeno ima prednostno pravico do uvedbe šole, deloma zaradi svojega uboštva, deloma zaradi neznanja o gojenju čebel. Lanšprež je njegovo središče in omogoča lahek dostop z vseh strani.

in čebelnjaka

3. Tu sta tudi dva čebelnjaka za šolanje, po deželnoknežjem predpisu primerna zaradi trajno menjajočega se cvetočega rastlinja, kar ustreza gojenju čebel od zgodnje pomladi do pozne jeseni, tako da sta vedno dovolj zasedena s čebelami. Eden od njiju je na vrtu gospostva, drugi četrt ure od tod pri nekem podložniku.

Pouk, učni čas in ure pouka 4. Pouk je brezplačen. Kar naj bi zadevalo plačo, sledi pod št. 13. Šola je vse leto, razen ob nedeljah in praznikih, in sicer vsak dan po dve uri, poleti zjutraj od sedmih do osmih, popoldan od štirih do petih, pozimi zjutraj od osmih do devetih, popoldan pa kakor poleti.

V čem obstaja pouk. 5. Po predpisih naj bi se v deželnem jeziku prav nazorno poučevala Janševa načela, uvod v čebelarjenje. Brez zadržka naj bi bile posebej razložene stvari in postopki, ki se jih on ne dotika. In pojasnjena naj bi bila vsa vprašanja, ki bi se pojavila. Z eno besedo, zvesto naj bi se poučevalo vse, kar je potrebno za poznavanje čebel, njihovega prehranjevanja, opraševanja in gojenja.

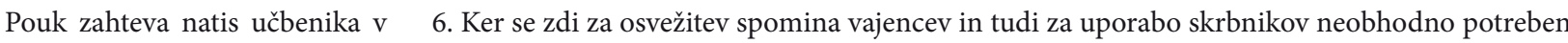
deželnem jeziku. $\mathrm{v}$ deželnem jeziku napisan učbenik čebelarstva, bo treba, če se ne najde tisti, ki sem ga sestavil jaz in ga poslal gospodu tajniku Kmetijske družbe, napisati novega, da bo z natisom v splošno korist, to pa zahteva trud in čas.

Raziskava deželnih čebelnjakov, 7. Potrebno bi bilo tudi prehoditi deželo, da se razišče in pospeši čebelarstvo, kar zadeva skupno koliko naj se razširijo. čebelarjenje (pod št. 16). Na to sem vedno pripravljen, in sicer zastonj. Kar pa zadeva druge, zasebne čebelnjake, sem na to pripravljen le toliko, kolikor bi se lahko tja pripeljal in bi to ne bilo v škodo pouku. Pripravljeni bi morali biti, da pridejo pome z vozilom, poskrbijo za prehrano in prevzamejo druge stroške, da bi se komu ne zahotelo in bi me nadlegoval iz čiste zlobe.

Preverjanje z Dunaja ni potreb- $\quad$ 8. Nobenih pomislekov ne bi imel podvreči se preverjanju z Dunaja, ko ne bi bilo visokih potnih no. stroškov in bi mi to dovoljevala starost. Vendar pa se mi zdi odveč. Ko bi tudi moja sposobnost ne bila znana širom dežele, sta pričujoči spis in Pouk čebelarstva izpod mojega peresa dovolj za odločitev glede mojega znanja in sposobnosti za javno poučevanje.

Letni izkaz vladi o stanju čebe- $\quad 9$. O čebelnjakih, izročenih mojemu nadzoru, o njihovem negovanju, hranjenju in njihovi čisti larstva. koristi sem pripravljen vedno podati vladi letni izkaz skupaj s poročilom o njihovem napredovanju ali nazadovanju $\mathrm{v}$ deželi, in ne potrebujem za to niti nasveta niti komisarjev, da bi me nadzirali in še manj usmerjali. Saj delajo tisti, ki se na stvar ne razumejo, le zmedo in lahko le zasolijo juho. Zraven tega bi me njihove vizite tudi preveč stale.

Svoboda, da to službo vsak trenutek lahko zamenjam s kom drugim, 10. Če pa bi imela visoka vlada do mene nezaupanje in bi se bala, da bi postal v poučevanju zanikrn ali bi izkoristil priložnost, da iz te službe napravim neobvezno početje, izjavljam, da sem jo pripravljen takoj, na prvi namig z veseljem prepustiti komu drugemu.

kot tudi, da jo lahko odložim ob 11. Obenem pa si jemljem svobodo, da lahko ob koncu vsakega leta dam na to službo odpoved, koncu leta. saj se nanjo ne obvezujem iz kake sebičnosti, ampak iz ljubezni do domovine in v pomoč podložnikom. Nihče pa ni varen pred tem, da ne bi bil za svojo dobrodelnost, kot se pogosto dogaja, občasno deležen nehvaležnega nadlegovanja ali sitnosti.

Voziti čebele na pašo lahko od- $\quad$ 12. Voziti čebele drugam na pašo se mi zdi nepotrebno, saj se v tem okrožju paša nenehno svetujem. spreminja, razen v času, ko cveti kostanj, ki ga tukaj ni. Zato sem pred dvema letoma tudi sam želel prestaviti čebele v Mirno Peč, vendar mi - sam ne vem iz kakšnih predsodkov - tamkajšnja soseska tega ni dovolila. 
Plača za poučevanje prepuščena lanšpreškim podložnikom.

Jemanje desetine od čebelnjakov.

Čebelarjenje naj se oprosti vseh dajatev.

Ukinitev zasebnih čebelnjakov.
13. Kar zadeva plačo v višini 300 goldinarjev, namenjeno učitelju čebelarstva, kakor tudi uporabo tretjine panjev, ki naj bi jih nabavila stanovska blagajna, to v celoti prepuščam svojim podložnikom proti zagotovilu, da bodo s tem kupili ustrezno število panjev in jih namestili v čebelnjake za skupno rabo ter jih vzdrževali za stalno vzrejo, kakor bom o tem obširneje razložil.

14. Skupni čebelnjaki naj bi bili v skladu z deželnoknežjo zahtevo bodisi prosto vsake desetine ali naj bi bilo vsaj prepovedano, da se ta jemlje v naravi.

15. Prav tako naj bi bili panji, ki se vozijo na pašo ali s paše, v skladu s patentom, datiranim na Dunaju 8. aprila 1775, št. 10 in dalje, oproščeni vsake cestnine ali drugih dajatev, ki jih predpostavlja mitnina. Čebelarjenje naj bi tudi ne bilo nikoli obremenjeno s kako posebno naklado bodisi za erarij ali za javne ali zasebne koristi, marveč naj bi bilo za vse čase deležno podpore s popolnim oproščenjem.

16. Kar zadeva 13. člen omenjenega patenta, da ima vsak podložnik pravico gojiti poljubno število panjev, bi bilo to v skladu s poročilom ( 80 ali 90 panjev) dovoljeno le $\mathrm{v}$ tistih krajih, kjer ni skupnih čebelnjakov, in to le v oddaljenosti pol ure hoda od njih, sicer pa naj bi bili ukinjeni vsi zasebni čebelnjaki. Stvar se bo v obdobju dveh let uredila sama od sebe, ker se ti ne bodo mogli upirati množici skupnih čebel.

Prevzem čebeljih proizvodov ali urbarialnih dajatev po tekoči ceni.
17. Proizvode skupnih čebelnjakov kot med in vosek ne bodo mogli prodajati nikomur razen meni in mojim naslednikom na gospostvu, da bodo tako posestne dajatve povsem pokrite. Sicer pa se obvezujem, da jih bom skladno z navadno srednjo ceno ob sejmu sv. Elizabete po odbitku običajnih 10 odstotkov tare, vozarine in drugih stroškov od njih odštel in upošteval razliko pri dajatvi.

Iz zgoraj povedanega je razvidno, da sem se za to odločil iz čiste ljubezni do podložnikov, kajti njim v olajšavo jim rad prepuščam ne le plačo, odmerjeno za učitelja čebelarstva, in uporabo pridobljenih vzrejnih panjev, ampak tudi pričakovane čebelarske proizvode, ki jih bom prevzel po pravični, $\mathrm{v}$ deželi običajni ceni brez vsakega dobička in obračunal namesto plačila $\mathrm{v}$ gotovini za druge dajatve, k čemur obvezujem tako sebe kot svoje naslednike.

\begin{tabular}{ll}
\hline B. pravilo & Osnutek za vajence \\
\hline $\begin{array}{l}\text { Prost, brezplačen dostop poleg } \\
\text { nastanitve. }\end{array}$ & $\begin{array}{l}\text { 1. Ko bo po predhodnem osnutku čebelarska šola potrjena, bo treba v deželi naznaniti, da ta } \\
\text { brezplačno poteka na Lanšprežu in da je vsakomur prosto dostopna. Tistim, ki so bolj oddaljeni } \\
\text { in ne morejo hoditi domov, ampak bi se morali, dokler ne bodo dovolj poučeni, tam trajno za- } \\
\text { držati, bo omogočeno tudi z brezplačno nastanitvijo. }\end{array}$
\end{tabular}

Hrana za vajence.

2. Tako bližnji kakor tudi oddaljeni vajenci, si bodo morali sami poskrbeti za hrano. Toda tistim, ki se bodo izven šolskih ur pripravljeni prostovoljno zaposliti pri oskrbi in delu na moji pristavi, pripada robotna pravica do dveh obrokov hrane na dan, in sicer bodo dobili enega zjutraj, drugega zvečer, da bodo lažje shajali.

Potrebne lastnosti vajencev. $\quad 3$. Vajenci naj bodo stari od 15 do 20 let, željni učenja, sposobni in olikani fantje, ne nevestni in nemoralni ali predani pijači, prepirljivosti in barantanju, sicer bodo kot nezanesljivi in neprimerni izključeni in odpuščeni. Če bodo vešči branja in pisanja vsaj v deželnem jeziku, bodo toliko bolj dobrodošli.

Koristilo bi jim znanje branja in $\quad$ 4. Če ne, jih bodo tega v kraju šolanja lahko naučili tudi moji gospodarski uslužbenci ob nedepisanja v deželnem jeziku. ljah in praznikih, vsaj kolikor dopusti kratka doba njihovega pouka. Drugega pa se bodo lahko naučili $\mathrm{z}$ lastno vajo, potem ko se bodo od tod poslovili. Stanovi bi lahko kot stranski zaslužek blagovolili za njihovo nagrado nakazati 50 goldinarjev letno, in to ne brez osnove.

Vzrok za to. 5. Ti fantje bodo lahko zelo koristili svojim gospostvom ne le s tem, da jih bo to nastavilo za skrbnike čebelnjakov, ki bodo vodili potrebno evidenco, ampak bodo lahko medtem opravljali tudi druga, za gospodarstvo koristna dela. A to prepuščam samim gospostvom in njihovim posebnim načrtom.

Dati v uk kandidate za vrtnarje. $\quad$ 6. Pač pa bi bilo v njihovo lastno dobro zelo priporočljivo, da bi pri izbiri kandidatov za pouk dali prednost predvsem tistim, ki jih že sicer nameravajo uporabiti za vrtnarje. Ker je večina čebelnjakov nameščenih v vrtovih, s tem zlahka prihranijo prejemek enega človeka. Saj se lahko vrtnarju, ki skrbi za vrt, izroči tudi oskrba na vrtu nahajajočega se čebelnjaka. 
Koristen zakon.

Začetek šole in prisotnost vajencev.

Pouk v izdelovanju panjev.

\section{C. pravilo}

Šest čebelnjakov, njihova izvedba in zasedba.

Sklad za nabavo čebeljih panjev.

O nespremenljivosti skupnega čebelarstva.

Pomnožitev družin ne bo za užitek,

marveč $\mathrm{v}$ prid na novo nameščenih skupnih čebelnjakov.

V čem obstaja skupni užitek.

Svoboda vstopa v to skupnost.
7. Zato naj bi se z zakonom uvedlo pravilo, da bi v prihodnje ne mogel biti odpuščen noben vrtnarski vajenec, ki se je obenem izučil tudi v čebelarstvu in bil v njem izprašan. Gospostvom bo pri tem v korist, da bodo imela ugledne čebelnjake v svojih vrtovih in da jih bodo lahko izkoriščala, ne da bi morala pomnožiti število svojih poslov. Morda bo ta predlog všeč visoki deželni vladi?

8. Z začetkom marca se začne tako čebelarsko leto, kakor pouk čebelarstva, konča pa se ob koncu meseca oktobra, ker pozneje pri čebelah ni več potrebe po zunanjem delu. Zato lahko tisti, ki so izdelali, takrat dobijo tudi dopust, medtem ko morajo slabši v zimskem času ponavljati in ostati v šoli, dokler se ne usposobijo.

9. V dolgem zimskem času naj da mizar, ki je pri meni v službi, vajencem, ki so ostali, da ponavljajo, kar zadeva gojenja čebel, tudi pouk v mizarstvu, da bodo ob svojem času znali napraviti potrebne panje in podloge za nje. Tako jih bodo mogli, bodisi da bodo sami gojili čebele. bodisi da bodo nastavljeni za skrbnike čebelnjakov, brez dodatnih stroškov napraviti in se z njimi oskrbeti.

10. Da bi dali vajencem spodbudo za čebelarjenje, bi po mojem nemerodajnem mnenju stanovi lahko dovolili in iz svoje blagajne dodelili za nagrado ne vsakemu, ki se je izučil, marveč vsaj tistim, ki so se v splošnokoristni umetnosti čebelarstva odlikovali pred drugimi, toliko denarja, da bi si mogli z njim nabaviti prvi panj in bi jim bila tako podarjena osnova za prihodnjo razširitev.

\section{Načrt za splošnokoristno čebelarsko vrtnarsko šolo pod gospostvom Lanšprež}

1. V skupno izkoriščanje gospostva samega kot njegovih podložnikov. Če mi Bog podaljša življenje, bom v šestih letih poverjenega mi čebelarstva napravil prav toliko skupnih čebelnjakov, se pravi po enega na leto, in jih opremil s po 120 panji. Zato potrebujem nujni material in mojstre, podložniki pa bodo morali brezplačno prispevati delovno silo in prevoz.

2. Za ustanovitev skupnega čebelarstva in za njegovo nadaljnje razširjanje v prihodnosti, s čemer bom svojim podložnikom olajšal oskrbljenost s hrano in davčni položaj, prepuščam svojo plačo 300 goldinarjev na leto, ki naj bi mi pripadala kot bodočemu učitelju čebelarstva, da se bo uporabila za nakup 120 panjev na leto. Kar pa zadeva dodatne stroške nakupa in prevoza, bom prispeval tudi za to in o tem leto za letom poslal visokemu uradu izkaz na vpogled.

3. Naj pri glavnici, ki jo bom uporabil za skupno čebelarstvo, za vse prihodnje čase tudi trdno ostane, naj je nihče ne ukine, niti ji osporava ali jo spremeni, kar velja tako zame, kot za moje naslednike in podložnike tega gospostva. Naj jo visoki urad ohranja in varuje, tako da se tudi pod pretvezo morebitne večje koristi od tega ne bo moglo niti najmanj odstopiti.

4. Da bi to skupno čebelarstvo pri omenjenem gospostvu bolj in bolj koristilo udeležencem, bo vmesni porast družin, bodisi da gre za spontane roje ali za umetno pogojene nove družine, povsem izvzet od skupnega užitka in ga ne bo mogoče tržiti, ampak

5. kakor hitro bo porast čebeljih panjev zadosten za naselitev novega čebelnjaka, se bodo odvečni panji /kolikor presegajo število 200/ vzeli s svojega položaja in prenesli v nov čebelnjak, seveda tokrat ponovno v skupni užitek gospostva Lanšprež in njegovih podložnikov. In tako spet in spet.

6. V skupni dobiček od gojenja čebel spada torej le med iz starejših satov, spodrezanih jeseni iz nastavkov, ter vosek iz panjev slučajno umrlih družin. Nasilnega morjenja čebel zaradi jemanja medu naj bo za vedno konec in naj se tega nihče ne loteva, če noče izgubiti deleža, ki mu pripada.

7. Vsakomur od lanšpreških podložnikov je dano, da lahko kadar koli in kolikor krat hoče stopi $\mathrm{v}$ skupno čebelarstvo, in to s poljubnim prispevkom bodisi v gotovini ali s panji ali da ob koncu leta izstopi. Pri vpisu naj se mu izda potrdilo tako o plačanem prispevku kakor o sumarnem stanju čebelnjaka, da se mu ob izstopu sorazmerni delež od prirastka nadomesti v denarju oziroma ob manku odvzame.

Nadzor zadeva gospostvo. $\quad$ 8. Nadzor in vodstvo skupnih čebelnjakov sta dana gospostvu Lanšprež, ki bo osebno ali po svojih uradnikih gledalo, da se večkrat tudi s sklicem skrbnikov in krajevnega odbora ob nedeljah in praznikih posvetuje o pomanjkljivostih in izboljšavah ter si prizadevalo, da jih uresniči. 
Potrebni odbor za vsak čebel- 9. Čeprav je dobra oskrba skupnega čebelnjaka v interesu vsakega podložnika in bi si moral zato njak. vsakdo prizadevati, da ob prostih urah obišče bližnji čebelnjak, pomaga skrbniku ob rojenju in pravočasno javi gospostvu, da odpravi morebitne pomanjkljivosti, bosta, da bi to dosegli, iz soseske vsakega čebelnjaka nastavljena dva pomočnika za nadzor.

Za skrbnika potrebna plača.

10. Vsak skupni čebelnjak potrebuje dobro poučenega skrbnika, ki bo od marca do konca oktobra od zgodnjega jutra do večera pazil na čebele in stal na preži, tako da ne bo mogel imeti dodatnega zaslužka. Glede na njegovo marljivost in uporabnost mu bo moralo gospostvo s pomočjo odbora določiti primerno letno plačo iz skupnega dobička.

Zaznamek in plačilo med letom 11. Vse med letom pri čebelarjenju nepogrešljive stroške, kot čebelarsko opremo, deske za panje nastalih stroškov. in čebelnjake ter drugo, bo založila gosposka in jih vpisala v skrbnikovo knjižico in si jih ob koncu leta iz skupnega dobička povrnila. Kar zadeva čebeljo krmo, izpodrezanih medenih satov, kar stane pri opravljanju mnogo truda, skrbi in lesa in pri čemer izpade velika izguba, se obračuna za pol več, kot je v deželi običajna letna cena.

12. Tako pri odvzemu zgornje naklade $\mathrm{v}$ začetku oktobra, kot pri tehtanju panjev, ki bodo ostali za naslednje leto, naj bodo poleg skrbnikov prisotni tudi odbori in neto teža medu, ki ga bo prevzelo gospostvo, naj se zapiše v skrbnikovo knjižico zaznamkov, da se podložniki prepričajo o svojem zmotnemu mnenju, ki ga imajo nasproti gospostvu.

Zaključek leta in polaganje ra12(!). Gospostvo mora ob zaključku leta v navzočnosti odborov in skrbnikov, pri čemer lahko čuna. svobodno prisostvujejo tudi podložniki, podati pojasnila o vseh prejemkih in izdatkih in o tem napraviti kratek izpis iz čebelarskega zapisnika. En prepis bo dan na vpogled podložnikom, drugi pa, skupaj z izkazom razdelitve in plačil, poslan deželni vladi.

Zimsko nadomestilo.

14. Tudi uradniku omenjenega gospostva se zaradi nadzora, vodenja računov in prepisov spodobi nadomestilo, ki naj bo prepuščeno razsodbi lastnika in odborov. To bi moglo biti precejšnje v primeru, če bo le-ta pripravljen poučevati lanšpreške podložnike v čebelarstvu in jim ob nedeljah in praznikih podajati moj pouk. Vendar pa je potreben čas, da se čebelarstvo dovolj razvije.

Deset odstotkov čistega dobička 15. Potem ko bo ob letnem obračunu z odbitkom izdatkov ugotovljen čisti dobiček od čebeje treba pustiti v blagajni. larstva, naj se od njega odtegne 10 odstotkov, najprej zato, da se pomnoži blagajniški prejem za napravo in postavitev novih čebelnjakov, a tudi za nakup novih panjev, ki bodo nadomestili tiste, ki so po nesreči umanjkali.

Potem pride na vrsto skrbnikova plača in končno izravnava za prispevke zasebnikov.

Razdelitev dobička med gospodom in podložniki.

16. Razdelitev presežka med gospostvom in podložniki je treba napraviti takole: Če bi moral v šestih letih učitelj dobiti 1800 goldinarjev plače, bi moralo temu ustrezno prav toliko pripasti podložnikom, in če bi zraven uporabil še 600 goldinarjev za nakup panjev, od katerih bi pripadel gospostvu ustrezen dobiček, bi morali torej podložnikom pripasti trije, gospostvo pa le en del presežka.

Razdelitev med podložnike. $\quad$ 17. Končno je treba pretresti vprašanje, kako naj se razdeli presežek med podložnike. Ali naj se razdeli po glavah vsem enak delež ali po popravljeni napovedi (podložniških dohodkov) ali po merilu njihovega uboštva, tako da bi se pri razdelitvi izključili premožnejši. Kar zadeva mene, se nagibam k poslednjemu, ker želim le pomagati revnejšim, nikakor pa ne bogatiti premožnejših. Vendar se bom pokoril sklepu visoke deželne vlade.

Vzrok, da želi gospostvo prevzeti nadzor.

Gospostvu ne bo povzročalo težav, da prevzame nadzor in vodstvo, deloma zaradi lastne koristi pri tem, največ pa zaradi ljubezni do podložnikov, ker bo s tem občutno olajšana njihova oskrbljenost s hrano in davčni položaj, še posebno, ker bodo v roku nekaj let njihove dajatve s prevzemom medu po srednji ljubljanski ceni z odbitkom vozarine, cestnine, tehtanja in drugih stroškov povsem pokrite. Če pa bi se izkazalo, da je gospostvo s prevzemom medu prikrajšano, bodo to podložniki po pravici imeli za neškodljivo, saj jim bo blagajna povrnila škodo. Podobno kakor se ob nesreči požara, ki zadene podložnike, po občem mnenju lahko za postavitev hiš napravi izplačilo iz skupne blagajne. 


\begin{tabular}{ll}
\hline D. pravilo & Pouk za skrbnika \\
\hline Vzreja je odvisna od dobrega & $\begin{array}{l}\text { 1. Dobra vzreja temelji predvsem na strokovno podkovanem, spretnem in neutrudnem skrbni- } \\
\text { su, kajti po njegovem ravnanju delajo in se ravnajo tudi čebele. Zato mora biti iznajdljiv, marljiv, } \\
\text { trezen, zvest in dobro vzgojen človek, sicer bo vzreja bolj nazadovala kot napredovala. }\end{array}$
\end{tabular}

Skrbnik mora svojemu gospodu o vsem poročati in izpolnjevati njegove ukaze

2. Skrbnik mora svojemu gospodu obširno poročati o vseh pripetljajih in dobesedno izvesti vse, kar mu naroči glede pomagal, ter pokorno izpolniti vse njegove ukaze. Ne sme si drzniti, da bi, posebno v težjih zadevah ravnal svojeglavo in samovoljno postopal brez predhodnega dovoljenja gospoda.

Ne sme se umakniti od čebel- $\quad 3$. Potrebna je njegova trajna prisotnost pri čebelnjaku vseh osem poletnih mesecev, da zaustavi njaka roparje, da opazi, če je panj brezmatičen in da ogrebe roje. Zato mu je strogo prepovedano, da bi se potegoval za dodatnimi zaslužki ali drugimi opravili, ne da bi to predhodno najavil in bi bil v času njegove odsotnosti nastavljen drug sposoben skrbnik.

Lahko pa ima postranski zaslu- 4. Prosti čas pa lahko hvalevredno izkoristi na primer s pletenjem, izdelavo slamnikov in drugih žek s pletenjem in podobnim reči, ki se skladajo z nadzorom nad čebelami, in si tako pridobi postranski zaslužek. Prav je, če se skrbnikom ponudi možnost, da se tega izučijo in se jim priskrbi potrebni material, tako da bodo vedno zaposleni in jih ne bo odvračalo od čebelnjaka.

Za to potrebna uta 5. Nekaj korakov proč od čebelnjaka, na eni od dveh strani na štirih stražnih mestih, je koristno namestiti poldrugo klaftro dolgo in klaftro široko streho za uto, pod katero se lahko skrbnik brani pred soncem in dežjem in kjer lahko medtem, ko pazi na čebele, tudi kaj dela. Če ni sposoben za drugo delo, se lahko ukvarja $\mathrm{z}$ izdelavo panjev.

Zapisnik o oštevilčenem panju $\quad$ 6. Skrbnik, ki zna pisati, vodi pravi zapisnik svojih panjev, ki jih označi s številkami na dve coli širokih in poldrugo colo visokih kovinskih ploščicah, zgoraj preluknjanih in označeni z napisom v oljni barvi. Te ploščice so z majhnim žebljičkom pribiti na panj in zadržijo številko, ki so jo enkrat dobili, dokler panj živi. Ob menjavi podstavkov prenese ploščice s prejšnjih na nove panje in jih pričvrsti nad žrelo, številke umrlih panjev pa da mlajšim.

Kaj je treba vpisati v zapisnik 7. V zapisnik se vpiše leto, dan, mesec in vrsta pridobljenega roja s številko panja od katerega izhaja. V zapisnik se vpišejo vsi pripetljaji vsakega panja, vpiše se teža letnega donosa medu in opiše stanje ob pregledu, da se je mogoče seznaniti z razmerami vsakega panja in se o njih poučiti iz zapisnika.

Pomladno čiščenje in pregled $\quad$ 8. Pogost pregled panjev je eno glavnih skrbnikovih opravil. Navadno ga opravi trikrat na leto. Najprej spomladi, potem ko so se čebele nekajkrat sprašile, in sicer na kak topel dan brez vetra, da čebele, ki odidejo na zrak ne otrpnejo od mraza in ne umrejo. Panj za panjem potegne ven, ne da bi ga obrnil, tako da ostanejo drobir in mrtve čebele na tleh, panj odpre in vse očisti, potem ponovno pritrdi dno in postavi na prejšnje mesto.

Na kaj mora pri tem gledati 9. Pri tem pregledu mora dobro raziskati a) moč družine, b) količino zalege, c) njihovo morebitno hudo gnilobo. Družine razvrsti v pet razredov in jih vpiše v zapisnik kot: zelo številne z D/1, številne $\mathrm{z} \mathrm{D} / 2$, srednje številne $\mathrm{z} \mathrm{D} / 3$, šibke $\mathrm{z} \mathrm{D} / 4$ in zelo šibke $\mathrm{z} \mathrm{D} / 5$.

Zapis ugotovitev kaj je treba ukreniti z zalego z hudo gnilobo

10. Enako se razume za zalego. Velik obseg zalege označi z Z/1, manj velik $z \mathrm{Z} / 2$, srednji z Z/3, majhne zalege z Z/4, nikakršne z Z/5, zalego z hudo gnilobo pa z GZ. Čebele iz tega panja čimprej prežene $\mathrm{v}$ prazen panj, tri dni in noči naj jo pusti gladovati, končno pa jo spet pretrese $\mathrm{v}$ prazen panj in jo prenese na mesto, umaknjeno od vseh čebel, ter jim takoj ponudi med za hrano, da ne bi preprosto umrle od lakote.

Tehtanje panjev, pri tem potreb- $\quad$ 11. Preden panj vstavi, ga stehta in njegovo čisto masoo v funtih vpiše v zapisnik. Ne le zato, da na pozornost bi vedel, koliko medu je vsak použil med zimo, ampak bolj zato, da bi slabše bolj zgodaj nakrmil. Če noče še v mrzlem času odtrgati satov mora pri čiščenju z nošnjo, odpiranjem, zapiranjem in tehtanjem panjev postopati zelo previdno.

Povzetek iz zapisnika 12. Potem ko preiskavo zaključi, naj na posebnem listu napravi povzetek iz zapisnika: A) panji z najmočnejšimi družinami, B) panji z največjo količino zalege, C) panji s šibkimi družinami in D) panji s šibko zalego, E) panji brez zalege - v ustrezni predelek vpiše s kovinske ploščice oznako panja - pod F pa vpiše panje, ki jim primanjkuje medu.

Kako je treba krmiti panje, ki 13. Panje pod F je zaradi pomanjkanja zaloge potrebno zvečer vsak drugi dan krmiti z medom jim primanjkuje medu $\mathrm{v}$ satu, nameščenem $\mathrm{v}$ kobilico, ki ima tri prste širok razmik in ki jo porinemo naravnost pod gnezdo, kajti ko bi se čebele pomikale nazaj, da se nasitijo, bi od mraza otrpnile ali se ponujene hrane sploh ne bi dotaknile. S takim krmljenjem nadaljujemo, dokler ni dobiti paše od zunaj. 
O panjih brez zalege, ki jih je treba ponovno pregledati

O panjih s šibko družino in zalego
14. Panje, vpisane pod E, mora čez nekaj tednov ponovno pregledati. Če spet ni najti zalege, pridruži tak panj drugemu, s srednje bogato zalego. Tak panj je namreč bodisi brez matice, ali je matica, če jo ima, neplodna. Preden panj podstavimo pod drugega, je treba matico poiskati in jo, če jo najdemo, odstraniti, sicer pride med njima do dvoboja in do nevarnosti, da bo slaba matica dobro ubila ali ranila.

15. Tudi panje pod C in D je treba po dveh, treh tednih ponovno pregledati. Če se njihova družina in zalega medtem ne pomnoži, jim je treba odvzeti matice in panje podtakniti drugim, srednje močnim panjem. Matic pa ne uničimo, ampak jih shranimo v škatlah skupaj s približno vrčkom čebel, ker jih še potrebujemo. Potem ko smo namreč podtaknjeni panj ojačali z drugim in se je njegova zalega okrepila, združena panja ločimo in damo matico nazaj v prejšnjega. Tako se število panjev ohrani.

O močnih panjih, kdaj jim 16. Ko se panji z zelo močno družino (A) in zalego (B), tako okrepijo, da v aprilu in maju do damo podstavke srede junija napolnijo $\mathrm{z}$ družino vse satovje od vrha do tal spredaj in zadaj ali celo posedajo pred žrelom, je zanje pravi čas, da jim damo podstavke in jih uporabimo bodisi za roje ali za pašne družine. Za te zadnje so določeni najstarejši panji in tisti, ki so zelo pozno rojili. Prvim je namreč potrebna obnova, tem pa oddih. Pomembni, bogato naseljeni in $\mathrm{z}$ mlado gradnjo opremljeni panji so namenjeni za rojenje in za narejence.

Kateri panji so namenjeni za roje ali za pašne družine?

17. Takim panjem ne smemo dati naenkrat več kot en podstavek. Čebele namreč vedno bolj pridno delajo, če prostor, ki smo jim ga priskrbeli, napolnijo z družino, kakor če je zanje prevelik. Ko pa novi podstavek skoraj izpolnijo od spredaj do zadaj, nastane iz tega bodisi družina za roje ali dobi, če je bil določen za pašno družino, od časa do časa novi podstavek, in sicer do začetka septembra, s čimer preprečimo kasno rojenje.

Drugo čiščenje in pregled $\quad$ 18. Drugi pregled napravi skrbnik ob kresu, da ugotovi

a) kateri panji so zaradi izrojenja morda ostali brez matice

b) in kateri imajo hudo gnilobo zalege.

Dalje zato, da slabotnejše panje in njihovo satje očisti gnilobe. Pri tem naj pazi na vse, kar je bilo povedano malo prej pod št. 9 o prvem pregledu, z izjemo zdaj nepotrebnega tehtanja, in naj vse vpiše v zapisnik.

Podstavki ob času cvetenja ajde za med na zalogo

19. Ta pregled bo dal skrbniku namig, katerim panjem naj da nastavke ali podstavke. Čas za to namreč že prihaja z bližajočim se cvetenjem ajde. Če ima torej na zalogi kak nastavek z medom, ga bo najprej podstavil panjem, ki so z njim siromašnejši, da dobijo čebele hrano, v zahvalo pa v najbolj nevarnem času ohranijo žerke. Ko skrbnik zaključi delo s podstavki z medom,

Kako vstavi prazne podstavke 20. obdrži prazne v pripravljenosti in dá vanje prazno satje in drobce voska. Kolikor voska namreč najdejo čebele $\mathrm{v}$ panju, toliko si prihranijo časa za izdelavo novega in prinesejo noter toliko več medu. Posebej pa naj na srednjo letvico podstavka prilota lep mlad sat velikosti dlani, ki služi čebelam namesto opore.

Opravilo skrbnika v času cvetenja ajde

21. V času cvetenja ajde je skrbnik brez dela in mora paziti le na to, da imajo čebele za delo dovolj prostora. $\mathrm{V}$ nasprotnem mora pravočasno vstaviti nove podstavke ali v primeru, da so združeni že štirje, imeti pripravljene dodatke, katerih vsak je pol čevlja dolg $(16 \mathrm{~cm}), 14$ palcev širok $(35 \mathrm{~cm})$ in tri in pol palca visok $(9 \mathrm{~cm}), \mathrm{z}$ vratci na utor spredaj in zadaj, po štirje, položeni drug na drugega, imajo višino in širino štirih podstavkov in se vrinejo od zadaj, sporazumevanje bo čebelam omogočeno skozi vehe, kar bo izdatno prispevalo k širjenju zalege.

(Opomba: Vsebina zapisa ni povsem razumljiva.)

in ob njegovem koncu

22. Kakor hitro bo skrbnik opazil, da se hočejo ob koncu cvetenja ajde čebele med seboj spopasti, naj poskrbi, da prepreči ropanje, tako da zoža žrela; ponovno je potrebna njegova nepretrgana navzočnost in pažnja. Oktobra je zaposlen z odvzemanjem gornjih, starejših nastavkov in izganjanjem čebel, ki so notri, nazadnje pa najspodnejših, ki še niso do konca zgrajeni in kjer so še po trije med seboj povezani. V primeru da je poln tudi ta, naj ga pusti čebelam, namesto njega pa ponovno odvzame gornjega.

Jesensko zapisovanje 23. Vse nastavke in podstavke, ki jih odvzame, označi z oznako panja, jih stehta in zabelež njihovo čisto maso, tako da bo vsa nabirka sešteta in zapisana. Vedeti mora, da bo družina prezimila v panju ob toliko enakomernejši toploti in se ohranila zdrava in živahna, čimbolj polno in strnjeno je zgrajeno njegovo satje. 
Zadnje čiščenje in pregled

24. O vseh svetih je tretje čiščenje in pregled, oboje povsem enako prvemu. Ob njem zapiše skrbnik čisto maso, preiskavo drobirja, morebitno prisotnost trotov in gnile zalege. Če naleti na katero od njih, naj jo povsem izreže, čebele z matico naj pomete po treh dneh v prazno spodnjo škatlo, jo porine na razprostrto laneno rjuho in jo pusti, da se sprašijo v svež, z medenim satjem preskrbljen podstavek, spomladi pa ga prestavi na oddaljen kraj, da se čebele ne vrnejo.

Jeseni je treba poskrbeti za med za krmljenje, na kaj je treba pri tem paziti

25. Jeseni mora skrbnik poskrbeti za svojo zalogo medu za vzrejo tako skupaj kot v satu. Pazi naj, da ne bi teh panjev prizadela gniloba, kakor tudi da ne bi vzel zraven tistih medenih satov, $\mathrm{v}$ katerih je še zalega. Čebele, ki bi to jedle, se bi pri tem okužile, med drugim pa bo začel vreti ves med, če pride vmes le ena celica. Panji, ki se hranijo z njim, bodo imeli hudo gnilobo.

Skrbnik naj vsak dan pregleda panje spredaj in zadaj

26. Skrbnik, ki izpolnjuje svoje dolžnosti, pregleda:

a) vsak dan zgodaj zjutraj panje, ki so mu zaupani, da ne bi morda med ponoči izvlečenimi mrtvicami opazil tudi matico,

b) zvečer med četrto in peto uro razišče, ali ni morda en ali drug panj postal nemiren. Kajti panji, ki so čez dan izgubili matico, jo ob tej uri pogrešijo in čebele jo skušajo z živahnim letanjem najti zunaj ali znotraj panja;

c) med neprestanim letanjem čebel naj gre večkrat mimo čebelnjaka, vendar previdno, da ne pohodi čebel, ki se plazijo po zemlji, in naj panj pregleda;

d) večkrat naj odpre končnico, pregleda panj spredaj in zadaj in se seznani z njegovim stanjem, mirno in prijazno naj pregleda tudi čebele. Če najde kaj sumljivega, odpre panj in pogleda v njegovo notranjost, da pravočasno prepreči kakršno koli zlo.

Krmljenje čebel

27. Eno največjih težav predstavlja krmljenje, ki ga je treba razen ob času zunanje medne paše pri vseh panjih izvesti vsak tretji dan, v času paše pa le ob dolgo trajajočem slabem vremenu. Pri krmljenju moramo biti bolj radodarni kot varčni, saj ničesar ne zavržemo. Čebele ne pojedo nič preko potrebe in to nadomestijo dvakrat, presežek pa pustijo v svojih panjih.

$\mathrm{V}$ dveh primerih naj bo posebno pogosto

28. Posebno v dveh primerih je treba panje obilno nakrmiti:

a) kadar so že pripravljeni na rojenje, a jim ga slabo vreme prepreči; kajti če jih ne nakrmimo čebele izpijejo nepokrito zalego, da se nasitijo, vendar vse leto ne rojijo več;

b) v času preprostega rojenja, kajti čim bolj jih krmimo, ker hrane ne pojedo in imajo še premalo zgrajenega sata, da bi poleg zalege prihranile presežek, se trudijo, da bi toliko več gradile; kakor hitro pa ne pokrivajo sata, lahko s krmljenjem prenehamo, prekinjene gradnje do ponovne paše ne bodo več obnovile.

Pri krmljenju moramo biti pazljivi, da preprečimo ropanje

29. Pri krmljenju naj skrbnik ravna previdno, da ne bi z medom umazal vratc navzven, kar je najpogostejši vzrok za privabljanje (čebel) roparic. Vonj jih privabi, da bi polizale med, in ko ničesar več ne najdejo, raziščejo vse odprtine. Ko katero najdejo, vdrejo noter, če pa ne najdejo nobene, si, ker je medtem njihovo število naraslo, drznejo naskočiti šibkejše družine. Ko jih premagajo, postanejo še drznejše in se spravijo na močnejše. Potem gre vse navskriž, da si človek ne zna več pomagati. Kakor majhna iskra pogosto zaneti velik požar, tako ena sama kaplja zgrešenega medu čebele pogosto tako razkači, da pride do krvavih bojev in do propada celih čebelnjakov.

Kdaj in kako je treba pozimi varovati čebele pred mrazom

30. Prva dva meseca nam panjev ni treba pokrivati razen ob dolgo trajajoči ohladitvi, ker so čebele $\mathrm{v}$ trajni otrplosti in le malo jedo, nasprotno pa jim, ko se zima prevesi, prija, da jih malo pokrijemo, ker se takrat močnejše že pripravljajo na zalegenje. $S$ tem naj bi nadaljevali do blizu konca maja, ker slana zalego pogosto shladi in povzroči gnitje, a potem jih lahko razkrijemo.

Druga oskrba pozimi 31. Drugače skrbnik pozimi nima dela, razen da pazi, da so žrela zožena, da prepreči mišim, posebno še rovkam, vstop v panj. Tudi zadaj mora pogledati, ker vratca, ki vpijajo vlago, večkrat izpadejo, znotraj se vgnezdijo miši, mraz objame družino, da zmrzne. Zato mora paziti, da so vratca vedno zaprta, oziroma naj jih ob straneh pričvrsti z žebljički.

Skrbnik ne more gojiti svojih čebel, lahko pa se vključi v sodelovanje.
32. Skrbnika, pa naj bo nastavljen pri skupnem čebelnjaku ali drugod, je treba odvrniti od tega, da bi gojil svoje lastne čebele, da se obrani vsakršnega suma nezvestobe pri krmljenju, rojenju itd. Če pa jih želi po jesenskem tehtanju dati v skupno rabo ali pristopiti k sodelovanju z denarjem, ima do tega pravico. Prav je, da mu to celo svetujemo, ker si bomo s tem zagotovili, njegovo še večjo marljivost. 